\title{
UJI PERFORMA MESIN DIESEL SATU SILINDER MENGGUNAKAN METODE STANDAR NASIONAL INDONESIA (SNI) 0119:2012
}

\author{
YAFID EFFENDI \& RIFAL \\ Program Studi Teknik Mesin, Fakultas Teknik, Universitas Muhammadiyah Tangerang \\ Jl. Perintis Kemerdekaan I/33 Cikokol-Tangerang \\ E-mail:yafid_effendi@yahoo.com
}

\begin{abstract}
ABSTRAK
Salah satu jenis mesin kendaraan bermotor yang sangat sesuai untuk transportasi dan kendaraan alat berat adalah mesin diesel, karena efisiensi pembakaran yang tinggi, kehandalan, fleksibilitas bahan bakar, dan rendahnya konsumsi bahan bakar membuat diesel banyak digunakan di beberapa Negara. Mesin traktor ini dimana dipasang motor horizontal yang didinginkan dengan air, mesin diesel traktor ini pemeliharaanya lebih murah dan harganya rendah, mesin diesel traktor ini dilengkapi dengan motor diesel vertikel dengan daya 10 PS atau lebih. Mesin diesel RD 85 DI 1S. Tujuan penelitian ini untuk mengetahui performa mesin diesel satu silinder. Metode yang digunakan eksperimen. Berdasarkan hasil penelitian ini, Nilai Daya Maksimal rata-rata $6.39 \mathrm{~kW}$ putaran maksimal $2200 \mathrm{rpm}$, dibandingkan dengan metode SNI 0119:2012. Daya, 5.60 - $6.71 \mathrm{~kW} / 2200-2600 \mathrm{rpm}$. Pada putaran $1600 \mathrm{rpm}$, Nilai Torsi yang dihasilkan sebesar $31.79 \mathrm{Nm}$, dibandingkan metode SNI 0119:2012, Torsi 25.48-33.45 Nm/1600-1900 rpm. Hasil Konsumsi Bahan Bakar $267.35 \mathrm{~g} / \mathrm{kW}$ jam pada putaran maksimal $2200 \mathrm{rpm}$, dibandingkan metode SNI 0119:2012, Konsumsi Bahan Bakar 230.56- $268 \mathrm{~g} / \mathrm{kW}$ jam. Performa mesin diesel RD 85 DI IS sesuai dengan SNI 0119:2012.
\end{abstract}

Kata Kunci: Performa, Mesin, Diesel, SNI

\section{PENDAHULUAN}

Negara Indonesia terkenal dengan pengolahan lahan merupakan salah satu proses yang sangat menentukan dalam hasil pertanian di Indonesia yang digunakan oleh para petani yang di Indonesia, sumber daya yang dilakukan oleh para petani yang ada di Indonesia untuk hasil pangan dihasilkan luasnya hasil lahan pertanian yang ada di Indonesia, Dari hasil pertanian yang ada di Indonesia salah satunya di kota jember jawa timur yang mengasilkan salah satunya dalam hasil pertanian bahan pangan yang dihasilkan para petani didaerah kota jember jawa timur dalam bidang produksi pertanian (Abdul halim, 2006)

Bertambahnya jumlah kendaraan bermotor dan krisis bahan bakar dianggap berdampak buruk pada lingkungan. Telah terbukti bahwa polutan dari emisi kendaraan bermotor berdampak signifikan terhadap sistem ekologi dan kesehatan manusia [Lei Zhu et all, 2010]. Salah satu jenis mesin kendaraan bermotor yang sangat sesuai untuk transportasi dan kendaraan alat berat adalah mesin diesel. Kontribusinya untuk kesejahteraan ekonomi, efisiensi pembakaran yang tinggi, kehandalan, fleksibilitas bahan bakar, dan rendahnya konsumsi bahan bakar membuat diesel banyak digunakan di beberapa negara [Zhiqiang Guo et all, 2011]. Meskipun memiliki beberapa keuntungan tersebut, mesin diesel memiliki masalah tentang pencemaran udara yang ditandai dengan adanya asap hitam atau gas buang sisa hasil pemakaran. $\mathrm{NO}_{\mathrm{x}}$ dan $\mathrm{PM}$ (particular matter) merupakan emisi paling tinggi yang dikeluarkan dari hasil sisa pembakaran mesin diesel dibandingkan $\mathrm{HC}$ (hydrocarbon) dan $\mathrm{CO}$ (carbonmonoksida) [Asif Faiz et all., 1996].

Mesin diesel traktor ini mempunyai sepuluh cakra berputaran dengan kecepatan 200-400 Rpm, mesin traktor ini dimana dipasang motor horizontal yang didinginkan dengan air, mesin diesel traktor ini pemeliharaanya lebih murah dan harganya rendah, mesin diesel traktor ini dilengkapi dengan motor diesel vertikel dengan daya 10 PS atau lebih. Sangat dibutukan untuk pertanian (Nakoela Soenarto, 2007)

Pemerintah telah mengelurkan mesin diesel traktor yang untuk pengolahan lahan pertanian yang ada di Indonesia yang hasil lebih cepat untuk mengolah lahan pertanian, penyempurnaan pengolahan lahan pertanian yang ada di Indonesia, hasilnya lebih baik lagi oleh para petani. Mesin diesel traktor ini merupakan solusi untuk dapat mengolah lahan dengan tepat dan cepat. Mesin diesel traktor rotary ini dengan mesin penggerak yang bertenaga maksimal, Mesin diesel traktor rotary diciptakan untuk mengolah lahan yang kering maupun basah dengan daya guna yang optimal mesin diesel traktor berkerja mengolah tanah dengan menggunkan pisau cakar yang berputar, untuk pembuatan bedengan (gulungan), dimana sangat 
deperlukan untuk menanam bagi para petani yang menggunakan mesin diesel traktor rotary ini. Mesin diesel traktor rotary ini juga sangat nyaman digunakan untuk membajak.

\section{METODOLOGI PENELITIAN}

Pengujian ini dilakukan eksperimen di Badan Pengkajian dan Penerapan Teknologi Balai Teknologi Termodinamika, Motor dan Propulsi. Kawasan Puspiptek GED.230. Serpong Tangerang.

\section{Daya}

Daya merupakan besarnya kerja telah dilakukan tiap satuan waktu. Besarnya daya mesin yang diukur dinamakan dengan brake power $(P b)$. Besarnya daya pengereman dapat diformulasikan sebagai berikut:

$$
\mathrm{P}=\frac{2 \pi N}{60} \times T \times 10^{-3}
$$

dimana $P$ adalah daya $(\mathrm{kW}), T$ adalah torsi $(\mathrm{Nm})$ dan $N$ adalah putaran kerja (rpm).

\section{Torsi (Brake Torque)}

Torsi merupakan ukuran dari kemampuan sebuah mesin untuk melakukan kerja. Besarnya torsi dapat ditentukan dengan mengukur beban mesin dan panjang lengan torsi. Pengukuran beban pada mesin dilakukan dengan dinamometer. Torsi dapat dirumuskan sebagai berikut:

$$
T=F \times b
$$

dimana $T$ adalah torsi $(\mathrm{Nm}), F$ adalah gaya penyeimbangan $(\mathrm{N})$ dan $b$ adalah jarak lengan torsi (m).

\section{Konsumsi Bahan Bakar Spesifik (BSFC)}

Konsumsi bahan bakar spesifik/Brake Spesific Fuel Consumption (BSFC) adalah laju aliran massa per satuan daya. Pengukuran ini dilakukan untuk mengetahui efisiensi mesin dalam menggunakan bahan bakar untuk menghasilkan daya. Secara matematis, konsumsi bahan bakar spesifik diformulasikan sebagai berikut:

$$
B S F C=\frac{\dot{m}_{f}}{P}
$$

dimana BSFC adalah konsumsi bahan bakar spesifik (kg/kW jam) dan $\dot{m}_{f}$ adalah laju aliran massa bahan bakar $(\mathrm{kg} / \mathrm{jam})$ dan $\mathrm{P}$ adalah daya $(\mathrm{kW})$

\subsection{Material Penelitian}

Material yang digunakan dalam penelitian ini bahan bakar solar, sedangkan spesifikasi bahan bakar dapat dilihat pada Tabel 1.
Table 1. Spesifikasi Bahan Bakar

\begin{tabular}{|c|l|c|}
\hline No & Parameter Uji & $\begin{array}{l}\text { Bahan } \\
\text { Solar }\end{array}$ \\
\hline 1 & Viskositas $\left(40^{\circ} \mathrm{C}\right) \mathrm{cP}$ & $2-5$ \\
\hline 2 & Nilai Kalor $(\mathrm{J} / \mathrm{gr})$ & 45213,80 \\
\hline 3 & Angka Cetana & 48 \\
\hline 4 & Densitas $\left(15^{\circ} \mathrm{C}\right) \mathrm{kg} / \mathrm{m}$ & 840 \\
\hline 5 & Flash Point ${ }^{\circ} \mathrm{C}$ & 60 \\
\hline 6 & Water Control $(\% \mathrm{v})$ & 0,05 \\
\hline
\end{tabular}

Pada Tabel 3.1 spesifikasi bahan bakar solar, salah satu bahan bakar mesin diesel yang banyak digunakan pada mesin traktor sawah, bahan bakar solar ini mudah terbakar sehingga engine mudah untuk dihidupkan

\subsection{Peralatan Penelitian}

1. Mesin Diesel RD 85 DI 1S, spesifikasi mesin diesel dapat dilihat pada Tabel 2.

Tabel 2. Spesifikasi Mesin Diesel 1 Silinder

\begin{tabular}{|l|l|}
\hline Nama & RD 85 DI 1S \\
\hline Type & $\begin{array}{l}\text { Horisontal, Pendingin, 4 } \\
\text { Langkah }\end{array}$ \\
\hline Kategori & Mesin Diesel \\
\hline $\begin{array}{l}\text { Diameter } \\
\text { Langkah }\end{array}$ & $88 \times 84 \mathrm{~mm}$ \\
\hline $\begin{array}{l}\text { Jumlah } \\
\text { silinder }\end{array}$ & 1 \\
\hline $\begin{array}{l}\text { Tenaga } \\
\text { Kontinyu }\end{array}$ & $7,5 / 2200 \mathrm{HP} / \mathrm{Rpm}$ \\
\hline Isi Silinder & $510 \mathrm{cc}$ \\
\hline $\begin{array}{l}\text { Torsi } \\
\text { Maksimum }\end{array}$ & $3.40 / 1600 \mathrm{KG} \mathrm{m/Rpm}$ \\
\hline $\begin{array}{l}\text { Tenaga } \\
\text { Maksimum }\end{array}$ & $8.5 / 2200 \mathrm{HP} / \mathrm{Rpm}$ \\
\hline Penyimbang & - \\
\hline $\begin{array}{l}\text { Sistem } \\
\text { Pembakaran }\end{array}$ & Pembakaran Langsung \\
\hline Jenis BBM & $\begin{array}{l}\text { Solar Dengan Kualitas } \\
\text { Baik }\end{array}$ \\
\hline Stater & Engkol Stater \\
\hline Arah Putaran & $\begin{array}{l}\text { Berlawanan } \\
\text { Putaran jarum Jam }\end{array}$ \\
\hline $\begin{array}{l}\text { Sistem } \\
\text { Pelumas }\end{array}$ & $\begin{array}{l}\text { Oli diedarkan Dengan } \\
\text { Pompa Trochord }\end{array}$ \\
\hline Isi Pendingin & 1,6 Liter \\
\hline $\begin{array}{l}\text { Pemakaian } \\
\text { BBM }\end{array}$ & 170 gr /Hp jam \\
\hline Isi Pelumas & 2,4 Liter \\
\hline $\begin{array}{l}\text { Sistem } \\
\text { Pendingin }\end{array}$ & Radiator \\
\hline Jenis Minyak & SAE 30 SAE 40 20W50 \\
\hline
\end{tabular}




\begin{tabular}{|l|l|}
\hline Pelumas & D10W30 \\
\hline Berat & $36 \mathrm{~kg}$ \\
\hline $\begin{array}{l}\text { Isi Tengki } \\
\text { BBM }\end{array}$ & 9,6 Liter \\
\hline Lampu & $\begin{array}{l}1232 / 32 \text { ( Dengan IC } \\
\text { Regulator) }\end{array}$ \\
\hline
\end{tabular}

2. Alat ukur temperature (Thermocopel).

3. Alat pengukuran daya Dynamometer Type Bull.

4. Alat pengukur emisi (Smokemeter).

5. Stopwatch.

\section{Mesin Diesel}

Mesin diesel yang akan digunakan didalam penelitian dapat dilihat pada Gambar 1.

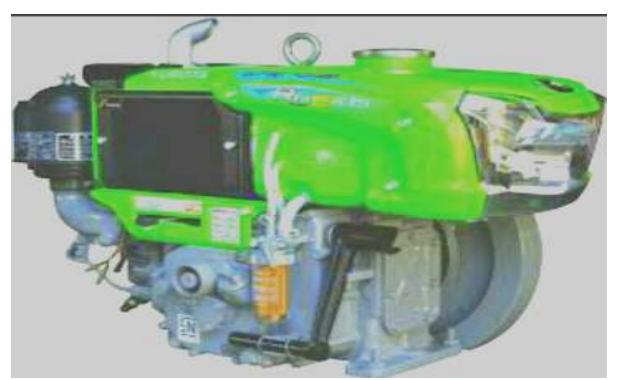

Gambar 1. Mesin Diesel

\section{Alat Uji AVS Inscreen}

Alat uji yang digunakan untuk mengukur tingkat asap secara otomatis, alat uji AVS Inscreen alat yang berbentuk monitor dilihat pada Gambar 2 .

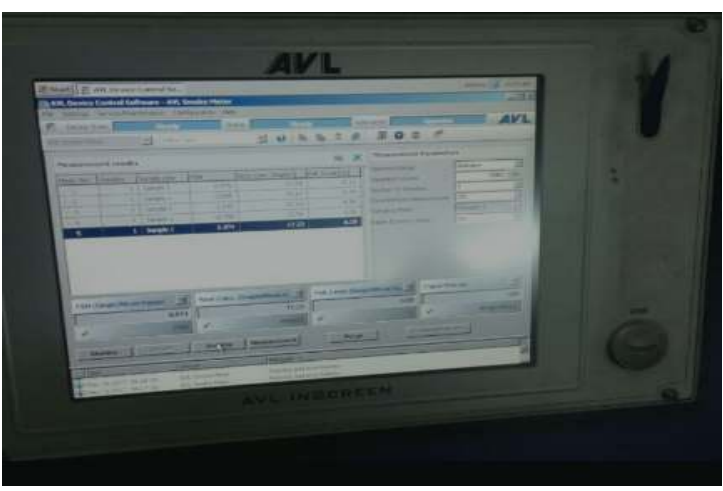

Gambar 2. Alat Uji AVS Inscreen

\section{Alat Uji Smoke Meter}

Alat yang akan menganalisa kandungan gas buang dan menghitung campuran udara,mengukur ketebalan asap gas buang pada bahan bakar yang berdasarkan Rpm mesin dilihat pada Gambar 3.

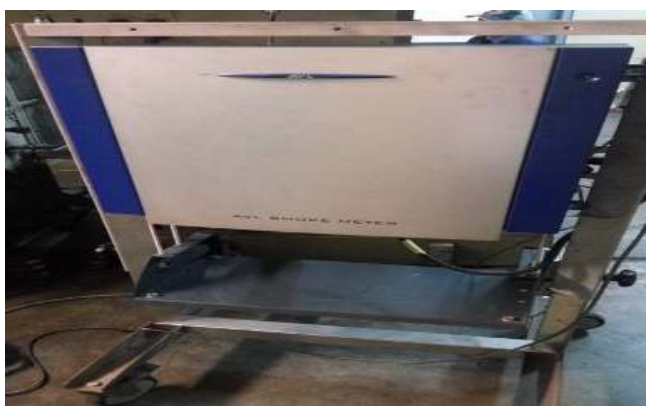

Gambar 3. AVL Smoke Meter

\section{Tangki Bahan Bakar}

Untuk mengukur dan mengalirkan bahan bakar ke mesin, tanki bahan bakar ini mempunya lima pemyimpanan bahan bakar dilihat pada Gambar 4.

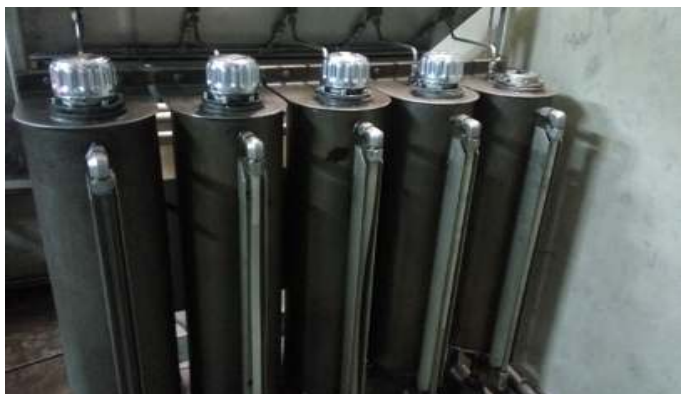

Gambar 4. Tangki Bahan Bakar

Digunakan untuk menghitung volume bahan bakar yang dikonsumsi oleh mesin uji selama pengujian. Pemakaian bahan bakar dihitung bersadasarkan waktu yang dibutuhkan untuk mengabiskan bahan bakar.

\section{Stopwatch}

Alat pencatat waktu disini digunakan untuk mengukur waktu pada saat pengujian mesin. Stopwatch yang digunakan dapat dilihat pada Gambar 5.

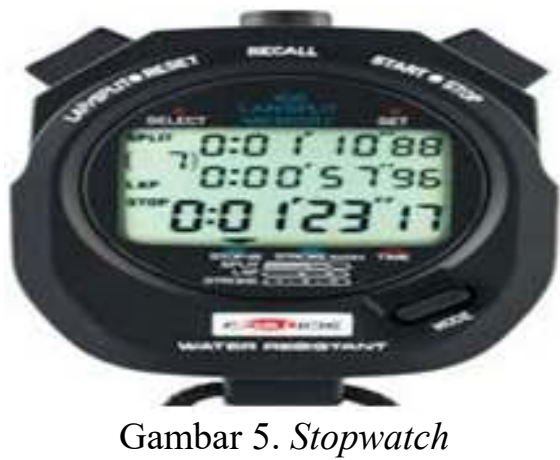

5. Thermocopel

Thermocopel yang akan digunakan dapat dilihat pada Gambar 6. 


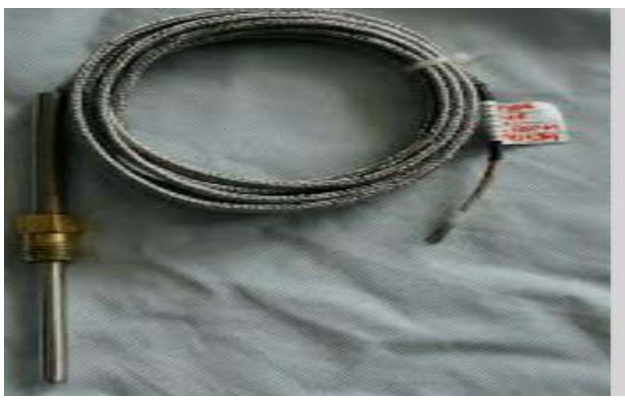

Gambar 6. Thermocopel

Thermocopel adalah alat untuk mengukur temperatur. Prinsip dari Thermocopel ini adalah dua buah metal yang berbeda digabungkan bersama, sehingga menimbulkan beda potensial jika salah satu ujungnya diberi panas. Dalam pemakaian Thermocopel diperlukan adanya suatu disply yang berfungsi untuk menampilkan nilai dari temperatur yang terukur.

\section{Dynamometer}

Untuk mengukur daya atau tenaga yang dikeluarkan atau dihasilkan dari suatu mesin dan dapat mengukur torsi dan putaran mesin dilihat pada Gambar 7 dan spesifikasi Dynamometer tampak pada Tabel 3.

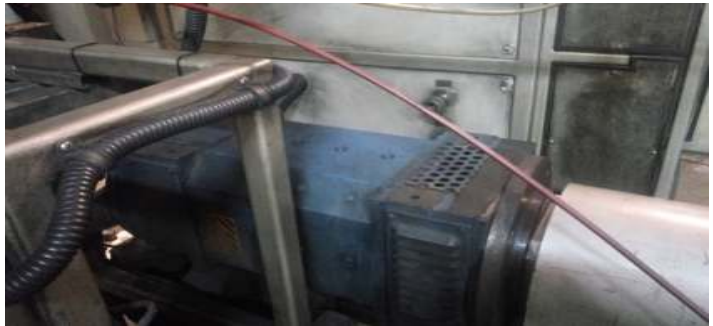

Gambar 7. Dynamometer

Table 3. Spesifikasi Dynamometer

\begin{tabular}{|l|l|l|}
\hline Type & \multicolumn{2}{|c|}{ Bull } \\
\hline Max Power & $30 \mathrm{Kw}$ & $15 \mathrm{KW}$ \\
\hline Max Torque & $95,5 \mathrm{Nm}$ & $47,7 \mathrm{Nm}$ \\
\hline Max Speed & $4000 \mathrm{Rpm}$ & $6000 \mathrm{Rpm}$ \\
\hline $\begin{array}{l}\text { Torquecalibration } \\
\text { accuracy }\end{array}$ & $\pm 025 \mathrm{Nm}$ & $\pm 0,125 \mathrm{Nm}$ \\
\hline Moment of inertia & $013 \mathrm{~kg} \mathrm{~m}$ & $0,11 \mathrm{Kgm}$ \\
\hline
\end{tabular}

Dynamometer mesin atau engine dyno digunakan untuk mengetahui besar jumlah tenaga atau daya yang keluarkan oleh suatu mesin, dynamometer mesin mengukur tenaga sebenarnya yang dari mesin.

\section{Komputer}

Untuk melihat hasil dari pengujian pada mesin secara otomtias dan untuk mengatur settingan pada mesin pada saat pengujian terlihat pada Gambar 8.

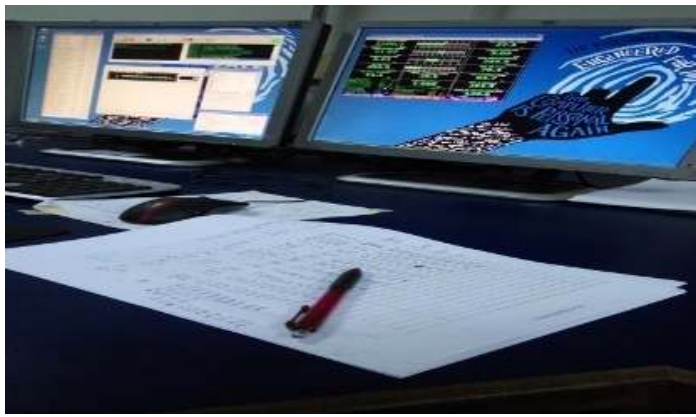

Gambar 8. Komputer

9 Thermohyrometer

Alat untuk mengukur suhu dan kelembapan udara basah dan kering pada suatu ruangan atau secara digital terlihat pada Gambar 9.

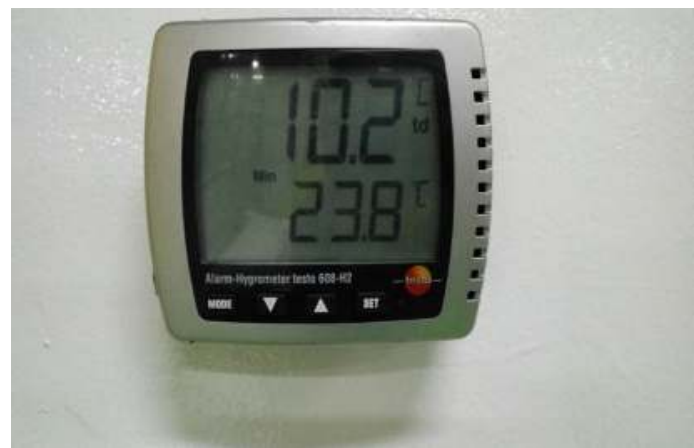

Gambar 9. Thermohyrometer

10. Blower / Pendingin

Untuk mendinginkan mesin pada saat pengujian dilihat pada Gambar 10.

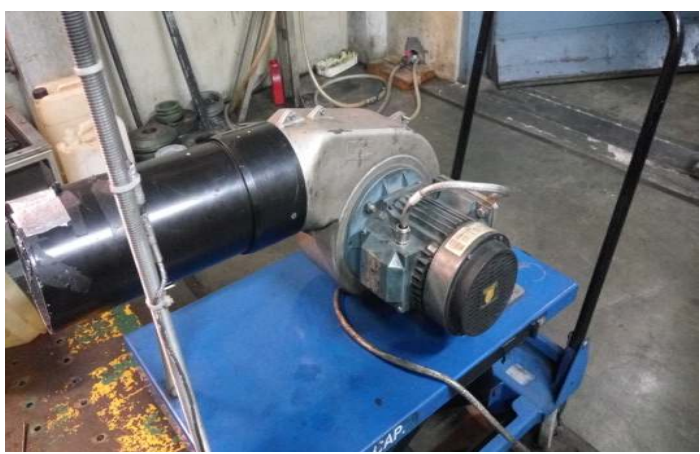

Gambar 3.28 Blower / Pendingin

\section{Pembuangan Asap}

Untuk pembuangan asap bahan bakar ke udara luar ruangan dilihat pada Gambar 11. 


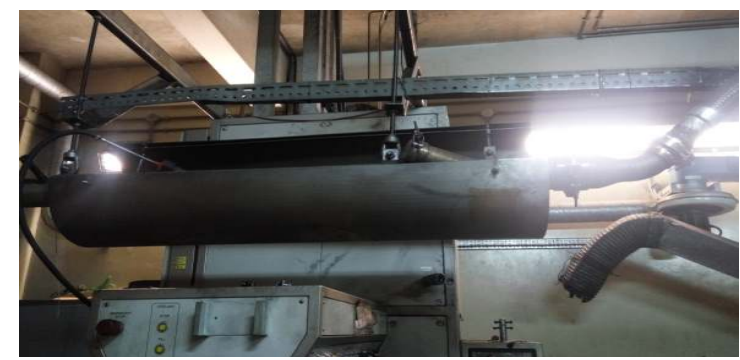

Gambar 11. Pembuangan Asap

\section{HASIL DAN PEMBAHASAN}

3.1 Hasil pengujian pada mesin diesel RD 85 DI $1 \mathrm{~S}$ 1. Daya (Engine Power $(\mathrm{kW})$ )

Pengujian daya maksimum dari 3 pengambilan data, tampak pada Tabel 4 dibawah ini.

Tabel 4. Data pengujian Daya dengan Putaran (rpm)

\begin{tabular}{|l|l|l|}
\hline Uji & Hasil Pengujian & \multicolumn{1}{|c|}{ SNI 0119:2012 } \\
\hline 1 & $6.42 \mathrm{~kW}-2200$ & $5.60-6.71 \mathrm{kw} / 2200$ \\
& $\mathrm{rpm}$ & $-2600 \mathrm{rpm}$ \\
\hline 2 & $6.33 \mathrm{~kW}-2200$ & $\begin{array}{l}5.60-6.71 \mathrm{~kW} / 2200 \\
-2600 \mathrm{rpm}\end{array}$ \\
& $\mathrm{rpm}$ & $\begin{array}{l}5.60-6.71 \mathrm{~kW} / 2200 \\
-2600 \mathrm{rpm}\end{array}$ \\
\hline 3 & $6.44 \mathrm{~kW}-2200$ \\
& $\mathrm{rpm}$ & \multicolumn{2}{|c}{} \\
\hline
\end{tabular}

Dari hasil pengujian Daya (Engine Power $(\mathrm{Kw}))$, hasil pengujian 1 pada putaran $2200 \mathrm{rpm}$ sebesar $6.42 \mathrm{Kw}$, pengujian 2 putaran $2200 \mathrm{rpm}$ sebesar $6.33 \mathrm{Kw}$, pengujian 3 putaran $2200 \mathrm{rpm}$ sebesar 6.44 Kw, dari spesifikasi Daya (Engine Power (kW)) Metode Standar Nasional Indonesia (SNI) 0119:2012, Daya 5.60 - 6.71 $\mathrm{Kw} / 2200-2600 \mathrm{rpm}$

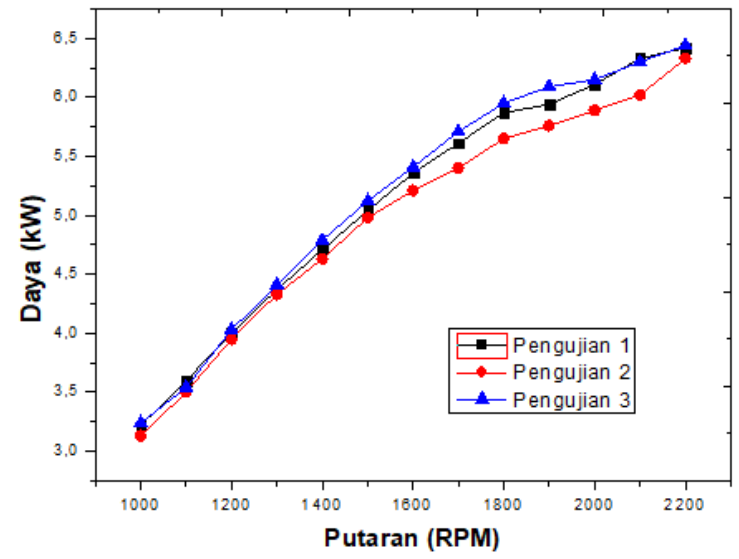

Gambar 12. Daya (Engine Power (kW))

Pada Gambar 12 terlihat bahwa daya efektif dari pola tekanan mesin diesel RD 85 DI $1 \mathrm{~S}$ meningkat dengan bertambahnya putaran mesin., Dari Gambar 4.31 dapat diketahui bahwa nilai daya tertinggi terjadi pada hasil pengujian ke 3 pada putaran maksimal $2200 \mathrm{rpm}$ sebesar $6.44 \mathrm{~kW}$, sedangkan pada pengujian ke 1 putaran $2200 \mathrm{rpm}$ nilai dayanya sedikit penurunan $6.42 \mathrm{~kW}$, tetapi pada pengujian ke 2 terjadi penurunan daya pada putaran maksimal $2200 \mathrm{rpm}$ sebesar $6.33 \mathrm{~kW}$, Dari hasil ketiga pengujian variasi pola pada tenakan mesin diesel RD 85 DI $1 \mathrm{~S}$ melihat dari spesifikasi yang menggunakan metode SNI 0119:2012 terdapat pada dikelas B $5.60-6.71 \mathrm{~kW} / 2200-$ $2600 \mathrm{rpm}$, pada putaran maksimal $2200 \mathrm{rpm}$ nilai daya $6.44 \mathrm{~kW}$ terdapat dari pengujian ke 3 .

\section{Torsi (Engine Torque (Nm))}

Pengujian Torsi dengan 3 sampel seperti pada Tabel 5.

Tabel 5. Data pengujian Torsi dengan Putaran (rpm)

\begin{tabular}{|c|l|l|}
\hline Uji & $\begin{array}{l}\text { Hasil } \\
\text { pengujian }\end{array}$ & SNI 0119:2012 \\
\hline 1 & $32.01 \mathrm{Nm} /$ & $25.48-33.45 \mathrm{Nm} /$ \\
& $1600 \mathrm{rpm}$ & $1600-1900 \mathrm{rpm}$ \\
\hline 2 & $31.10 \mathrm{Nm} /$ & $25.48-33.45 \mathrm{Nm} /$ \\
& $1600 \mathrm{rpm}$ & $1600-1900 \mathrm{rpm}$ \\
\hline 3 & $32.27 \mathrm{Nm} \mathrm{/}$ & $25.48-33.35 \mathrm{Nm} /$ \\
& $1600 \mathrm{rpm}$ & $1600-1900 \mathrm{rpm}$ \\
\hline
\end{tabular}

Dari hasil pengujian (Engine Torque (Nm)), hasil pengujian 1 pada putaran $1600 \mathrm{rpm}$ sebesar $32.01 \mathrm{Nm}$, pengujian 2 putaran $1600 \mathrm{rpm}$ sebesar $31.10 \mathrm{Nm}$, pengujian 3 putaran 1600 rpm sebesar 32.27, dari spesifikasi (Engine Torque (Nm)) Metode Standar Nasional Indonesia (SNI) 0119:2012, $25.48-33.45 \mathrm{Nm} /$ $1600-1900 \mathrm{rpm}$

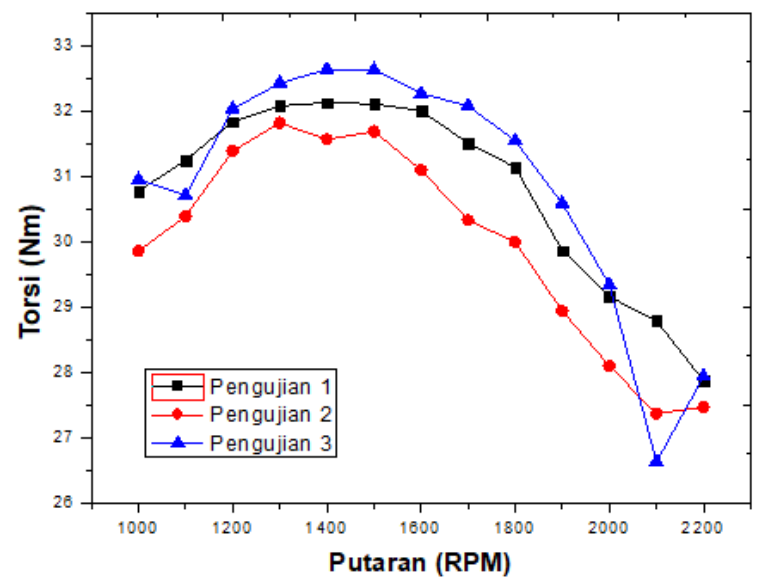

Gambar 13. Torsi mesin (Engine Torque (Nm)) 
Gambar 13 terlihat bahwa torsi yang efektif pada tekanan mesin diesel RD 85 DI 1S yang meningkat dengan bertambahnya putaran mesin, pada Gambar 4.32 dapat diketahui bahwa torsi tertinggi pada tekanan pengujian ke 3 pada putaran $1600 \mathrm{rpm}$ sebesar $32.27 \mathrm{Nm}$, pada saat putaran $2200 \mathrm{rpm}$ penurunan sebesar $27.94 \mathrm{Nm}$, kemudian pada saat pengujian ke 1 pada putaran $1600 \mathrm{rpm}$ nilai torsinya sedikit penurunan 32.01 $\mathrm{Nm}$, putaran $2200 \mathrm{rpm}$ sebesar $27.87 \mathrm{Nm}$, sedangkan pada pengujian ke 2 pada putaran $1600 \mathrm{rpm}$ torsinya sedikit penurunan $31.10 \mathrm{Nm}$, putaran $2200 \mathrm{rpm}$ torsinya sebesar $27.47 \mathrm{Nm}$, Dari hasil ketiga pengujian pada tekanan mesin diesel RD 85 DI $1 \mathrm{~S}$ melihat dari spesifikasi yang menggunakan metode SNI 0119:2012 terdapat pada dikelas B, $25.48-33.45 \mathrm{Nm} /$ 1600 - $1900 \mathrm{rpm}$, setalah dilakukan dari hasil pengujian terdapat pada nilai torsi sebesar 32.27 $\mathrm{Nm}$ pada putaran maksimal $1600 \mathrm{rpm}$ pada pengujian ke 3 .

\section{Konsumsi Bahan Bakar (Spesifik Fuel Consumption (g/kW hr))}

Konsumsi bahan bakar dengan 3 pengambilan data tampak pada tabel 6 dibawah ini.

Tabel 6. Data pengujian Spesifik Fuel Consumption putaran (rpm)

\begin{tabular}{|c|c|c|}
\hline Uji & Hasil Pengujian & SNI 0119:2012 \\
\hline 1 & $\begin{array}{l}273.21 \mathrm{~g} / \mathrm{kw} \mathrm{hr} \\
2200 \mathrm{rpm}\end{array}$ & $230.56-268.0$ \\
\hline 2 & $\begin{array}{l}263.07 \mathrm{~g} / \mathrm{kW} \\
2200 \mathrm{rpm}\end{array}$ & $230.56-268.0$ \\
\hline 3 & $\begin{array}{l}265.67 \mathrm{~g} / \mathrm{kW} \mathrm{hr} \\
2200 \mathrm{rpm}\end{array}$ & $230.56-268.0$ \\
\hline
\end{tabular}

Dari hasil pengujian, Spesifik Fuel Consumption (rpm) hasil pengujian 1 pada putaran $2200 \mathrm{rpm}$ sebesar $273.21 \mathrm{~g} / \mathrm{Kw} \mathrm{hr}$, pengujian 2 putaran $2200 \mathrm{rpm}$ sebesar $263.07 \mathrm{~g} / \mathrm{Kw} \mathrm{hr}$, pengujian 3 putaran $2200 \mathrm{rpm}$ sebesar $265.67 \mathrm{~g} / \mathrm{Kw} \mathrm{hr}$, dari spesifikasi Spesifik Fuel Consumption (rpm) Metode Standar Nasional Indonesia (SNI) 0119:2012, $230.56-268.0 \mathrm{~g} / \mathrm{Kw} \mathrm{hr}$

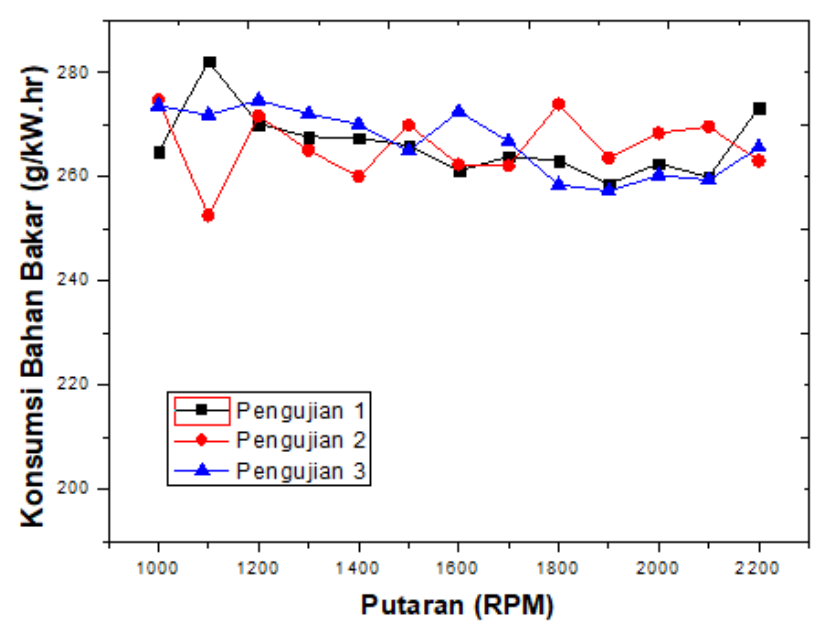

Gambar 14. Konsumsi Bahan Bakar (Spesifik Fuel Consumption(g/kW hr))

Gambar 14 dapat diketahui bahwa nilai dari hasil pengujian ke 1 putaran maksimal $2200 \mathrm{rpm}$ maka nilai sebesar $273.31 \mathrm{~g} / \mathrm{kW} \mathrm{hr}$, sedangkan pada pengujian ke 2 pada putaran $2200 \mathrm{rpm}$ sedikit penurunan pada Spesifik Fuel Consumption sebesar $263.07 \mathrm{~g} / \mathrm{kW} \mathrm{hr}$, kemudian pada saat pengujian ke 3 pada putaran $2200 \mathrm{rpm}$ dapat meningkat sebesar $265.62 \mathrm{~g} / \mathrm{kW}$ hr. Dari hasil ketiga pengujian pada mesin diesel RD 85 DI 1S melihat dari spesifikasi yang menggunakan metode SNI 0119:2012 terdapat pada dikelas B, $230.56-268.0 \mathrm{~g} / \mathrm{kW} \mathrm{hr}$, setalah dilakukan hasil pengujian ke 3 terdapat pada putaran maksimal $2200 \mathrm{rpm}$ nilai Spesifik Fuel Consumption $265.67 \mathrm{~g} / \mathrm{kW} \mathrm{hr}$.

3.2 Syarat Lulus Uji Performa Mesin Diesel RD 85 DI 1S berdasarkan Standar Nasional Indonesia (SNI) 0119:2012

Hasil pengujian performa mesin diesel dengan perbandingan SNI 0119:2012 seperti pada Tabel 7 dibawah ini.

Tabel 7. Hasil pengujian Performa Mesin Diesel dengan perbandingan SNI 0119:2012

\begin{tabular}{|c|c|c|}
\hline $\begin{array}{l}\text { Performa } \\
\text { Mesin } \\
\text { Diesel }\end{array}$ & $\begin{array}{c}\text { Hasil } \\
\text { Pengujian }\end{array}$ & SNI 0119:2012 \\
\hline Daya & $\begin{array}{c}6.39 \mathrm{~kW} \\
2200 \mathrm{rpm}\end{array}$ & $\begin{array}{l}5.60-6.71 \mathrm{~kW} / \\
2200-2600 \mathrm{rpm}\end{array}$ \\
\hline Torsi & $\begin{array}{l}31.79 \mathrm{Nm} \\
1600 \mathrm{rpm}\end{array}$ & \\
\hline $\begin{array}{l}\text { Konsumsi } \\
\text { bahan } \\
\text { bakar }\end{array}$ & $\begin{array}{l}267.35 \mathrm{~g} / \mathrm{kW} \\
\text { jam }\end{array}$ & $\begin{array}{ll}230.56- & 268 \\
\mathrm{~g} / \mathrm{kW} \text { jam. } & \end{array}$ \\
\hline
\end{tabular}


Berdasarkan data pengujian yang dilakukan dengan 3 sampel dibandingkan dengan SNI 0119:2012, hasilnya sesuai dengan SNI 0119:2012.

\section{KESIMPULAN}

Berdasarkan pembahasan dalam penelitian ini maka dapat disimpulkan sebagai berikut:

1. Nilai Daya Maksimal rata-rata $6.39 \mathrm{~kW}$ putaran maksimal 2200 rpm, dibandingkan dengan metode SNI 0119:2012. Daya, 5.60 - $6.71 \mathrm{~kW} /$ 2200-2600 rpm.

2. Pada putaran $1600 \mathrm{rpm}$, Nilai Torsi yang dihasilkan sebesar $31.79 \mathrm{Nm}$, dibandingkan metode SNI 0119:2012, Torsi 25.48-33.45 Nm/ 1600-1900 rpm.

3. Hasil Konsumsi Bahan Bakar $267.35 \mathrm{~g} / \mathrm{kW}$ jam pada putaran maksimal $2200 \mathrm{rpm}$, dibandingkan metode SNI 0119:2012, Konsumsi Bahan Bakar 230.56- $268 \mathrm{~g} / \mathrm{kW}$ jam. Performa mesin diesel RD 85 DI 1S sesuai dengan SNI 0119:2012.

\section{DAFTAR NOTASI/ISTILAH}

\begin{tabular}{|l|l|l|}
\hline Lambang & Nama & Satuan \\
\hline$b$ & Panjang lengan torsi & {$[\mathrm{m}]$} \\
\hline$F$ & Gaya & {$[\mathrm{N}]$} \\
\hline$\dot{m}$ & Laju aliran massa & {$\left[\mathrm{kg} \mathrm{s}^{-1}\right]$} \\
\hline$N$ & Putaran mesin & {$[\mathrm{rpm}]$} \\
\hline$P$ & Daya & {$[\mathrm{kW}]$} \\
\hline$T$ & Torsi & {$[\mathrm{Nm}]$} \\
\hline
\end{tabular}

\section{DAFTAR PUSTAKA}

Asif Faiz, Walsh Michael P, Weaver Christopher S,"Air Pollution From Motor Vehicles, Standards and Technologies for Controlling Emissions", The World Bank Washington, D.C, USA, 1996.

Heywood, John B.L, 1988, "Internal Combustion Engine Fundamentals”, McGraw-Hill, Inc, United States of America.

Ismanto, 2012, Analisa Viriasi Tekanan Pada Injektor Terhadap Performa (Daya dan Torsi) Pada Motor Diesel. Jurnal Teknik Vol 2, April 2012.

Johan Budi Harjanto, 2008, Penuntun Praktikum Teknologi Perlengkapan Mesin Diesel Vol 1. Restu Agung, Jakarta.

Kristanto, 2002, Bahan Bakar Pada Motor Diesel Sistem Injeksi Langsung. jurnal Teknik Mesin UK Petra,Vol 4.
Lei Zhu, C.S. Cheung, W.G. Zhang, Zhen Huang,"Emissions characteristic of a diesel engine operating on biodiesel and biodiesel blended with ethanol and metanol", International Journal of the Total Enviroment, Number 408, ScienceDirect, 2010.

Nakola Soenarto, 2007, Motor Serba Guna, PT Pradnya Paramita Jakarta.

Philip Kristanto,2015, Motor Bakar Torak, Andi Yogyakarta.

Zhiqiang Guo, Tianrui Li, "Combustion and emission characteristic of blends of diesel fuel and metanol to diesel", International Journal of Fuel, Number 90, ScienceDirect, 2011. 